\title{
Making Markets for Merit Goods: The Political Economy of Antiretrovirals
}

\section{Ethan B. Kapstein and Josh Busby}

\begin{abstract}
This paper examines the role of policy entrepreneurs and global activists in shaping the international market for antiretroviral drugs to combat HIV/AIDS. When ARVs first came on the market in the 1990s they were exceedingly expensive; the cost of treatment was upwards of $\$ 10,000$ per year. These drugs were thus accessible only to those patients who had high incomes. But in 2006, the "international community," meeting at a United Nations General Assembly Special Session (UNGASS), made an astonishing pledge to those who were infected with HIV. It proclaimed that there should be universal access to ARV treatment. This UNGASS, following up on an earlier historic UN special session devoted entirely to AIDS in 2001, marked the first time in history that the international community pledged itself to chronic care for the ill, which in this case includes the approximately 30 million people around the world estimated to be HIV positive. How do we explain the transformation of ARVs from private goods, which only a few could afford, into merit goods that were (at least declaratively) to be made available to everyone? In other words, how does a norm of "universal access to treatment" - that no person should be denied these life-extending drugs-become the ethical basis for global public policy with respect to pharmaceutical allocation? What are the lessons of the ARV story for other global issues? These are the primary questions we explore in this paper. Briefly, we argue that the policy entrepreneurs and activists who promoted the creation of a universal access to treatment regime — of the transformation of ARVs into global merit goods—relied on a combination of moral arguments and ideas with favorable material circumstances. From the ethical perspective, the task of these entrepreneurs was to convince the "international community" that access to ARVs was a "human right," or conversely to convince decision-makers that it was morally wrong to allocate these life-enhancing drugs solely on the basis of ability to pay. But from a material standpoint, these arguments were greatly facilitated by the lowering prices of ARVs caused by a combination of differential pricing (that is, lower prices for drugs in the developing world than in the advanced welfare states) and competition from generics producers, coupled with increases in foreign aid spending devoted to HIV/AIDS and other diseases.
\end{abstract}

Keywords: HIV/AIDS, ARVs, antiretrovirals, activists, policy entrepreneurs, merit goods, international community, global public health, global public policy, foreign aid
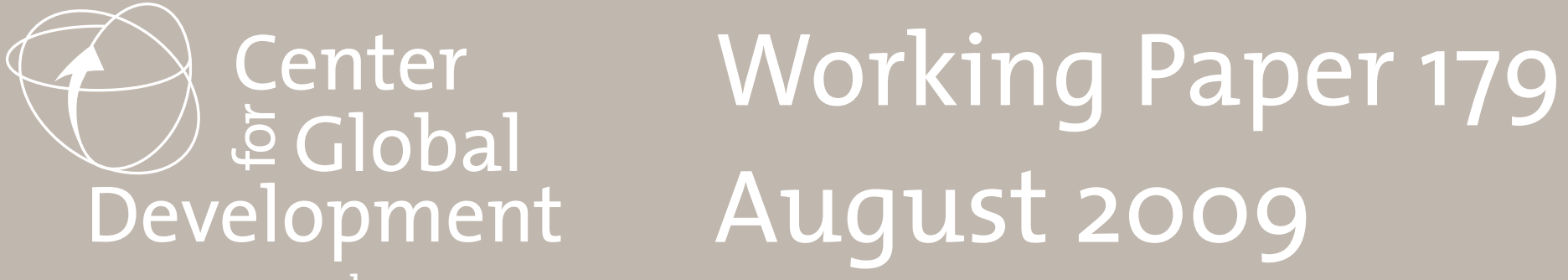


\title{
Making Markets for Merit Goods: The Political Economy of Antiretrovirals
}

\author{
Ethan B. Kapstein \\ Center for Global Development and University of Texas at Austin \\ ekapstein@cgdev.org \\ Josh Busby \\ LBJ School of Public Affairs, University of Texas at Austin \\ busbyj@austin.utexas.edu
}

July 2009

Revised: August 2009

Ethan B. Kapstein is a visiting fellow at the Center for Global Development. For 2009-2010, he is the Dennis O'Connor Regent's Professor in Business at the McCombs School of Business, and professor of public policy at the Lyndon Baines Johnson School of Public Affairs, both at the University of Texas at Austin. Josh Busby is an assistant professor at the Lyndon Baines Johnson School of Public Affairs, University of Texas at Austin. They wish to thank the Merck Foundation for its support of this research and Pranab Bardhan and Kim Elliott for comments on earlier drafts

This paper was made possible by financial support from the Bill \& Melinda Gates Foundation.

Ethan B. Kapstein and Josh Busby. "Making Markets for Merit Goods: The Political Economy of Antiretrovirals.” CGD Working Paper 179. Washington, D.C.: Center for Global Development. http:/www.cgdev.org/ content/publications/detail/1422655

Center for Global Development 1800 Massachusetts Ave., NW Washington, DC 20036

202.416 .4000

(f) 202.416 .4050

www.cgdev.org
The Center for Global Development is an independent, nonprofit policy research organization dedicated to reducing global poverty and inequality and to making globalization work for the poor. Use and dissemination of this Working Paper is encouraged; however, reproduced copies may not be used for commercial purposes. Further usage is permitted under the terms of the Creative Commons License.

The views expressed in this paper are those of the author and should not be attributed to the board of directors or funders of the Center for Global Development. 


\section{MAKING MARKETS FOR MERIT GOODS: THE POLITICAL ECONOMY OF ANTIRETROVIRALS}

\footnotetext{
"The scale-up of antiretroviral therapy is the most ambitious public health undertaking of our lifetimes. We are making history..." (Gonsalves 2008)
}

This paper examines the role of policy entrepreneurs and global activists in shaping the international market for antiretroviral drugs to combat HIV/AIDS. When ARVs first came on the market in the 1990s they were exceedingly expensive; the cost of treatment was upwards of $\$ 10,000$ per year. These drugs were thus only accessible to those with high incomes or exceptionally good health insurance, and gay activist groups - notably the militant organization ACT-UP — targeted pharmaceutical companies and insurance providers, along with government agencies like the U.S. Food and Drug Administration (FDA), in their efforts to obtain greater accessibility for AIDS victims through reduced prices, quicker approval processes for new therapies, and better coverage for this disease (d'Adesky 2004; Kramer 2003; Johnson and Murray 1988; Smith and Siplon 2006). This "first-generation" of AIDS activists, however, operated primarily in the United States and France (and later to great political effect in Brazil and South Africa), and they were mainly domestic — as opposed to global or cosmopolitanin their political orientation, meaning that the changes they sought from government and business regarding expanded ARV access were focused on their home polities rather than at the global level. 
But in the year 2006, the "international community," meeting as a United Nations General Assembly Special Session (UNGASS), made an astonishing pledge to those who were infected with HIV. It declared that there should be universal access to ARV treatment. This UNGASS, following up on an earlier historic UN special session devoted entirely to AIDS in 2001, marks the first time in history that the international community has set a policy goal of chronic care for the ill—of establishing what Mead Over has labelled an international "entitlement scheme" (Over 2008) — which in this specific case includes the approximately 30 million people around the world estimated to be HIV positive (UN General Assembly 2006).

How do we explain the transformation of ARVs from private goods, which only a very few victims of AIDS could afford, into merit goods or entitlements, defined as goods that should be made available to everyone, irrespective of their ability to pay for them (Musgrave 1959)? In other words, how does a norm of "universal access to treatment" - that no person should be denied life-extending drugs_-become the ethical basis for global public policy with respect to pharmaceutical allocation? These are the primary questions we explore in this paper.

Briefly, we argue that the policy entrepreneurs and activists who promoted the creation of a universal access to treatment regime did so by using compelling moral arguments while enjoying favorable material conditions or circumstances. From the ethical perspective, the task of these entrepreneurs was to convince political leaders and the broader public that it was morally wrong to allocate antiretroviral drugs solely on the basis of an individual's ability to pay. From a material standpoint, these arguments were greatly facilitated by the falling prices of ARVs after the turn of the millennium caused 
by a combination of differential pricing strategies by pharmaceutical manufacturers (that is, lower prices for drugs in the developing world than in the advanced welfare states) and price competition from generics producers of these drugs, coupled with increases in foreign aid spending devoted to HIV/AIDS and other diseases - changes that activists helped to bring about. In short, by fusing the moral and the material realms into an effective political campaign, AIDS activists transformed antiretroviral medicines into global merit goods. A crucial question for the future, however, concerns the sustainability of the universal access to treatment regime given the "Great Recession" that began in 2008, "donor fatigue" with respect to AIDS and the emergence of other priorities, and the growing demand for "next generation" therapies as existing treatments lose their effectiveness.

Beyond its importance to all those concerned with HIV/AIDS and global public health, we believe that the ARV case also has relevance well beyond those particular spheres. After all, in recent years activists have demanded that, inter alia, education, bed nets, clean water, sanitation, and many other goods be made available to every individual, irrespective of their ability to pay. But few if any of these demands have been met by multilateral declarations of support which are then backed by ample funding. This fact raises the question: under what circumstances does the international community make both the political and financial commitment that is required to generate global merit goods? Based on the AIDS case, we hypothesize that the bigger the political coalition in support of the merit good, the more likely that good is to emerge. And while that statement may sound trivial or self-evident, we would do well to recall that many worthwhile campaigns fail for the simple reason that they are unable to attract the 
widespread support that is needed to bring about significant social change. Creating such a coalition, we note, is difficult enough in the specific context of most nation-states (think of health policy reform in the United States), but it must be all the more challenging when activists must work trans-nationally, confronting different legal and cultural norms in the process. And as with ARVs, any campaign to bring about universal access to the provision of a given good must consider the sustainability of the funding stream.

The paper proceeds as follows. First, a brief summary history of the political response to AIDS in the developing world is provided by way of background. Second, we explain why AIDS treatment constitutes a puzzle for scholars. Third, we sketch a model of the supply and demand of global merit goods, using ARVs as our example. In the fourth section, we provide a provisional explanation that accounts for the relative success of the AIDS treatment campaign compared to other advocacy efforts. We conclude with a discussion of the applicability of the ARV case as a model for other health issues and other issue-areas in the global economy.

\section{The Global Politics of AIDS: A Brief History}

The AIDS crisis is a tragedy of epic proportions. By 2007, more than 25 million people had reportedly died from AIDS, 2 million of them in that year alone. ${ }^{1}$ Another 33 million were living with the virus. There were an estimated 2.7 million new infections in 2007, 1.9 million of them in sub-Saharan Africa, the epicenter of the pandemic (UNAIDS 2008b). In 2004, AIDS was the leading cause of death worldwide for people aged 15-59 (Kaiser Family Foundation 2005). In this section we provide a brief overview of the

\footnotetext{
${ }^{1}$ By way of comparison, the Black Death killed about 25 million in the $14^{\text {th }}$ century, possibly as much as $1 / 3$ of Europe's population (Peterson and Shellman 2006).
} 
international community's response to this tragedy, which ultimately led to the "political declaration" made by the members of the United Nations in 2006 that antiretrovirals should be made available on the basis of universal access.

Despite the fact that AIDS was first identified in the 1980s, public policy to attack the disease lagged far behind its spread for many years, at least in part because the majority of its victims — which included the so-called "4-H Club" of homosexuals, Haitians, heroin addicts, and hemophiliacs — were outside the mainstream of industrial world polities (Behrman 2004). In the United States, President Ronald Reagan saw little political gain from attacking a disease that was mainly associated with the gay lifestyle, and some evangelical ministers even preached that AIDS was God's vengeance on homosexual men. As a consequence, few health policy leaders within the administration were willing to increase domestic much less international funding for AIDS in any significant way (Garrett 1994). This situation would be surprisingly slow to change, and even President Bill Clinton during the 1990s was accused by AIDS activists of failing to give the disease the policy attention they believe it deserved (Schwartz 1994).

By the turn of the millennium, however, a confluence of events created the impetus for broader international action to address the pandemic. By this time, AIDS had in fact been largely contained within the advanced industrialized countries, thanks to a combination of prevention strategies and improved treatment options based on antiretroviral medications. With the invention of new drug treatment therapies, and with the near universal extension of these drugs to AIDS sufferers throughout the advanced industrialized world, the number of people dying from AIDS fell dramatically and instead the HIV virus was transformed into a chronic condition that many people could live with 
indefinitely. But with these ARV drugs costing more than $\$ 10,000$ a year as late as 2000 , the number of people with access to them in the developing world was, of course, miniscule, and so AIDS would continue its deadly spread there unabated.

For reasons we will now explore, this population would not be allowed to die silently, and a growing chorus of activists, policy entrepreneurs, and academics began to call for expanded access to treatment. Champions of developing world AIDS victims within international organizations, like the late Jonathan Mann of the World Health Organization and Peter Piot of UNAIDS (the United Nations umbrella agency which focuses on global AIDS) used their well-springs of knowledge, charisma, and energy to bring the crisis to the attention of senior decision-makers. In so doing, they used a variety of medical, economic, ethical, and security-related arguments about why antiretroviral treatment should be made available to the poor, drawing together a broad political coalition in favor of developing world access to ARVs (Piot 2009). Indeed, the fact that AIDS touched so many "nerves" in so many different communities—-from health workers to those in the defense and intelligence fields - greatly facilitated the task of coalition building and, in turn, the building of political support for a universal access to treatment regime (Elster 1993, makes a similar point about the importance of political coalitions in the advanced welfare states with respect to how scarce resoures, like health care or elite higher education, get allocated). These actors also relied on a growing body of evidence concerning the impact that AIDS was having throughout the developing world. Academic sociologists like Tony Barnett documented the devastating effects of HIV/AIDS on communities in Africa (Barnett and Whiteside 2002), while economists like Jeffrey Sachs drew attention to the consequences of the disease for future development and growth 
(Attaran and Sachs 2001). Sustained media coverage of global AIDS in 1999 and 2000, led by such journalists as Laurie Garrett at Newsday and Barton Gellman at the Washington Post, brought the human tragedy onto the front pages of the world's leading newspapers. All these efforts would combine to help push the issue higher onto the policy agendas of both public officials and of the activist community (Behrman 2004; Gellman 2000).

At the same time, the success in relatively poor countries like Brazil and Haiti in putting HIV-positive individuals on treatment, and Uganda's reportedly successful AIDS prevention program, helped make the case that global action could in fact be effective, thus negating the arguments made by some prominent public officials (like USAID Administrator Andrew Natsios) that ARVs required the kind of medical infrastructure that was only found in the industrial world.

As AIDS worked its grim way around the world, leaving in its train a growing number of casualties, the United Nations Security Council in 2000 devoted a meeting solely to disease, calling it a threat to peace and security. Soon after, in July 2000, Durban hosted the first international conference on AIDS to be held in Africa. This gathering was widely regarded by the AIDS community as the decisive turning point at which the idea of extending treatment to the developing world was deemed both medically feasible and morally necessary, since many of the developing world success stories with respect to treatment were presented at this time (Garrett 2009).

With the idea of broader access to ARV treatment now advancing on the international agenda, policy entrepreneurs like Peter Piot sought political support from the growing number of activist organizations that were beginning to take up this cause 
(Piot 2009). As we will show in a following section, these efforts by policy entrepreneurs and activists were ultimately about the transformation of ARVs from private goods which only the wealthy could purchase to merit goods that were available to everyone. In essence, they were focused on the political construction of a universal ARV market (Bartley 2007, 299). Thus, organizations like Doctors without Borders, Health GAP, Oxfam, and the Consumer Project on Technology (CPT) focused their advocacy work largely on loosening the market constraints imposed by the regime governing trade in intellectual property rights (TRIPS) on access to essential medicines, and they would play an important role providing legal and economic advice to developing countries with respect to challenging international trade laws. Other groups like the Global Aids Alliance, ACT-UP, and South Africa's Treatment Action Campaign (founded in 1998) would also achieve a critical voice with national governments in the debates over universal access to ARVs.

These movements would further benefit from the political work of the broader non-governmental development community. In particular, as the Jubilee 2000 campaign wound down (which had focused on debt relief for the developing world), many of the activists associated with this cause began turning their attention to AIDS. Perhaps most prominently, the Irish pop star Bono formed DATA (Debt Aids Trade Africa) in 2002, which quickly became one of the leading organizations engaged on the issue; indeed, President George W. Bush among other American political leaders was strongly influenced by Bono (who, fortuitously, was able to speak to them on a "Christian to Christian" basis) on global AIDS policy, as we will discuss in further detail below (Lefkowitz 2009). 
This broad ethical movement would also receive a tremendous boost at the turn of the millennium with the emergence of low-cost generic versions of ARV drugs, produced by manufacturers in such countries as Brazil and India. The success of the Brazilian government's campaign to treat the nation's AIDS victims with generics demonstrated that these drugs were not only effective in the developing world setting, but also that the costs of treatment could be contained. As a result, campaigners could begin to put a realistic price tag on the goal of universal access, and it was one that seemed within reach of the industrial world's foreign aid programs.

These ongoing campaigns gradually began to bear fruit. In 2001, the World Trade Organization (WTO) in Doha elaborated the rights of poor countries to override pharmaceutical patents and issue compulsory licenses for public health emergencies, and it extended the transition period from 2006 to 2016 within which least-developed countries had to offer patent protection to the pharmaceutical industry under the provisions of the TRIPS regime; in these negotiations developing countries were advised by such organizations as Oxfam and CPT (Fleet and N'Daw 2008). As the WTO began to support greater flexibility for developing countries to produce and later to import "cheap" generic ARVs, international donors began to scale up their commitments to finance treatment in the developing world.

Prior to 2002, the international community had provided only paltry resources aimed at the HIV/AIDS crisis in the developing world. As already noted, Attaran and Sachs had shown that less than $\$ 200$ million a year was being spent on global HIV/AIDS activities (Attaran and Sachs 2001, 57). They suggested that a multi-billion dollar fund should be created to extend treatment access and prevention to the millions who needed 
ARVs. In April of that year in a speech in Nigeria, UN Secretary General Kofi Annan picked up their call and sought donor approval for a new special fund to fight AIDS. In 2002, donors agreed that a new financing vehicle, the Global Fund to Fight AIDS, TB, and Malaria, should be created, though Washington's concerns about the UN's administrative capacity ensured that the Global Fund became an independent agency. Soon after the Global Fund's creation, donors created a number of bilateral programs of their own. Most notable was President's Bush five year \$15 billion plan announced in his 2003 Station of the Union Address. PEPFAR, the President's Emergency Plan for AIDS Relief, would become the world's biggest vehicle for AIDS spending. With the creation of the Global Fund and other bilateral and multilateral programs, donors rapidly scaled up funding for HIV/AIDS treatment and prevention programs, making available about $\$ 8.7$ billion in 2008 (Kates, Lief, and Avila 2009). Treatment received the largest proportion of funds, remarkable given that the extension of anti-retroviral therapy (ARV) to the developing world was dismissed as inappropriate for developing countries just a few years earlier. ${ }^{2}$ While funds from the global community only put about three million HIV-positive individuals in middle and low income countries on ARV therapy by the end of 2007, this was up from 400,000 at the end of December 2003 (WHO 2008b). ${ }^{3}$

Annan's initial estimate of the need for \$8-12 billion annually for global AIDS has since been scaled up as the broader devastation of the disease has become clear.

\footnotetext{
2 The original legislation for PEPFAR, for example, required by law at least $55 \%$ of the funds be spent on treatment. A May 2007 U.S. Government Accounting Office (GAO) report estimated that 32\% of the Global Fund's resources for AIDS were being dedicated to treatment, compared to $30 \%$ for prevention, $14 \%$ for care and support, and $24 \%$ for other (including health systems capacity strengthening) (GAO 2007).

${ }^{3}$ As of September 30, 2007, the U.S. estimated that the U.S government was supporting more than an estimated 1.44 million people to be on anti-retroviral drug therapy, up from 155,000 in September 2004 (Office of the U.S. Global Aids Coordinator 2007).
} 
UNAIDS has thus begun to seek support for orphans and for the development of health infrastructure and the education of health professionals. In 2008, UNAIDS estimated $\$ 22.1$ billion would be needed that year to combat the epidemic in low and middleincome countries, but only $\$ 15.6$ billion was actually provided (Kates, Lief, and Avila 2009). Still, these financial commitments had grown from almost nothing in the 1990s to billions of dollars within a very short period of time, alongside the "political declaration" that the international community had made in 2006 to provide universal access to treatment. In the next section, we sketch out how unexpected and puzzling this turn to universal treatment really was.

\section{Why AIDS Treatment is a Puzzle}

As Evan Lieberman has noted, “"The idea that long-term therapy ought to be provided to every person infected with HIV (at a clinical stage when such medication would be appropriate) was unimaginable to most global actors, let alone to policymakers and activists in the developing world, certainly in the early 1990s, and generally through that decade" (Lieberman 2009, 99). Why was this so and what makes the subsequent turn to AIDS treatment such a puzzle? In this section we explore some of the reasons for considering ARVs a "hard case" for international cooperation in public health.

First, it must be recalled that medical treatment is not generally based on regimes of universal access. Even within the advanced industrial nations, medical treatment is often allocated on the basis of income or need. There is, for example, no universal access to heart transplants or even to many types of cancer treatment, much less a commitment to provide universal access to treatment for chronic diseases like diabetes. 
Second, AIDS is not a disease that meets the conditions for eradication. Unlike smallpox or polio, there is no vaccine and the prospects for discovery of a vaccine do not appear promising any time soon (Brown 2008). Nonetheless, the international community embarked on an ambitious agenda to halt the spread of AIDS and keep people with HIV alive via treatment. The commitment to AIDS treatment is arguably the most sweeping international commitment to global public health since the ill-fated effort to eradicate malaria in the aftermath of the Second World War (Yekutiel 1981; Packard 1997). Certainly, the scale of funding and attention to AIDS by governments exceeds the funding for smallpox and polio. While those campaigns were ambitious, the funds for smallpox were trivial by international standards (less than $\$ 100$ million between 19591979) (Barrett 2006), and the bill for polio was mostly footed by one non-state actor, the Rotary Club, which has invested more than $\$ 600$ million in the endeavor over the past couple of decades (Rotary International 2007). Again, the availability of a vaccine in these cases meant that effective, relatively low-cost action could be taken on a global scale.

A third issue that makes this case a puzzle is that AIDS treatment is an extremely costly commitment. AIDS is costly in part because of the scale of the program but also because treatment is ongoing for the life of the patient. The promise of treatment is what Mead Over calls an international "entitlement" like Social Security or Medicare in the United States. Over estimates that by 2016 the United States alone could be spending as much as $\$ 12$ bn per year on treatment in developing countries, equivalent to about half of all U.S. overseas development assistance in 2006 (Over 2008). 
A fourth puzzling aspect of the turn to treatment has been the relative inattention paid to prevention, which should in principle be a more efficient approach for attacking the disease. Once ARVs became available, extended treatment became the main pillar of the international response. PEPFAR, the U.S. bilateral response, was mandated in its first five years to spend at least $55 \%$ of its funds on treatment and still must spend at least $50 \%$ on treatment and care after the 2008 reauthorization (Kaiser Family Foundation 2008). The Global Fund, for its part, spends nearly half of its funds on treatment (for all three diseases under its purview) (Global Fund Undated). AIDS is a disease that is preventable, and the commitment to universal access to treatment ultimately depends on a successful prevention strategy, lest the numbers of those needing treatment be beyond the capacity of governments to support. Indeed, that has sadly already happened with approximately 2.7 million new infections in 2007 (UNAIDS 2008a). Estimates of treatment needs accordingly have been revised upwards as the prevention agenda succumbed to politicization.

A fifth reason why the turn to treatment was so surprising is that the disease has historically affected communities that were marginalized from their own societies and/or from the international community. The international commitment to treatment is, on its face, an unlikely arena for domestic political gain: why would politicians make a commitment to poor foreigners, disproportionately from sub-Saharan Africa, for treating a disease that has historically been identified domestically in donor countries with groups (homosexuals, immigrants, IV drugs users, prostitutes) that have been marginalized and behaviors that have been highly stigmatized? 
A sixth reason why the international AIDS treatment regime is something of a puzzle is that it is unclear whether the billions being spent on this program would be the first or principal priority of African publics if they were making the policy decisions. In the 2002 Afrobarometer polls of Botswana, Uganda, Malawi, Mozambique and South Africa, AIDS was not the top priority in any of those countries. Even in Botswana and South Africa which boasted some of the highest prevalence levels in the world, AIDS was only the third and fourth highest priority respectively. In Uganda and Malawi, AIDS was the $11^{\text {th }}$ and $12^{\text {th }}$ highest priority identified by their respective publics (de Waal 2006, 8). Thus, in this sense, the international community has helped steer resources for a particular purpose, what Tobin referred to as "specific egalitarianism" (Tobin 1970), in ways that reflect donor priorities but perhaps not those of Africans themselves (though AIDS sufferers certainly have benefited from this choice).

Given these reasons, the emergence of an AIDS treatment regime was unlikely and unexpected, making an explanation of how it came about all the more compelling, both for understanding the past and also, as we discuss in the conclusion, for providing some suggestive explanations and lessons for other issue-areas within the broad arena of international cooperation.

\section{Making the Market for ARVS}

"You can't say to your patients, 'sorry you are dying of market failure'." - Zackie Achmat, Treatment Action Campaign (quoted in d'Adesky 2005)

As we have seen, the political economy of antiretrovirals evolved considerably during the period 1990-2006. Initially, these therapies were only available to those who could afford to buy them either because their incomes were high enough or because their 
insurance policies provided coverage; in this sense ARVs were quintessential private goods, produced by profit-maximizing drug manufacturers for first-world consumers. By the turn of the millennium, however, the international community had pledged universal access to antiretrovirals, meaning that they could and should be available to everyone with AIDS.

In this section we explore the political economy of the universal access policy. More generally, we seek to conceptualize ARVs as a class of "merit goods," meaning goods that are made available to a community of individuals (which could be the world population) irrespective of their ability to pay (Musgrave 1959). A distinguishing feature of contemporary "global civil society" is its cosmopolitan claim that many goods which are now considered to be merit goods in most of the industrial countries or welfare states of the north—such as universal access to education—should be available globally to all persons as well (see, for example, www.campaignforeducation.org). Understanding the politics of how ARVs became merit goods may thus yield broader policy lessons.

In this section we take up the task of conceptualizing ARVs as merit goods by building a simple analytical framework. We note that merit goods are unlike public goods in that they are potentially excludable and rival; once merit good A is produced, it is not necessarily available to all consumers, and my consumption of good A may prevent you from also consuming it. The lack of access to merit good A can be due to constraints on either the supply or demand sides of the equation.

On the supply side, the market may not produce enough of the good that society desires; an example would be provided by particular medical technologies that only serve a small percentage of those who are stricken by a given disease or ailment. Thus, in the 
case of ARVs, in a world with a fixed quantity of these drugs, my consumption of a pill or capsule means that you cannot also have it. At the same time, companies and health providers allocate access to the good by virtue of market prices and insurance. The (utilitarian) policy problem is that those who lack the means to purchase these goods may be excluded from enjoying them, with the concomitant loss of social welfare.

On the demand side of the market for merit goods, the constraints facing consumers are both more complicated and more contested by economists; thus, people may not demand a certain good—say medical treatment—-for different reasons which may easily be conflated, including a lack of income, lack of information (about the benefits of the treatment), or lack of foresight (about the future consequences of not receiving treatment today). In practice, these different constraints may be hard to separate; someone with little income at the present time, for example, may have less concern about his or her future prospects than someone whose income permits investment in expensive medical care.

It is thus crucial to recognize that merit goods could be, and indeed often are, produced by the private sector in something akin to a "free market" setting. As noted earlier, merit goods may well display the properties of private goods. Unlike classic public goods like clean air and national defense which are non-rival and non-excludable, merit goods are more like club goods, exhibiting qualities of both scarcity and excludability. The significant ideational and material challenge facing activists and policy entrepreneurs who wish to promote universal access to a particular good, therefore, is to transform private goods into merit goods. 
An interesting case in point along these lines is provided by an "Ivy League" university education. The Ivy League schools have traditionally served the American elite, largely the children of wealthy families. In recent years, however, these schools have moved increasingly toward "need blind" admissions policies, or admission which does not take into consideration the financial background of the applicant, in a bid to attract more students from the lower economic classes. College applications are thus judged on the basis of some (admittedly contested) concept of "merit" like test scores and academic achievement in high school. In this sense, the Ivy League universities have transformed the educational opportunities they offer individuals from private goods into merit goods.

Why have the Ivy League universities acted in this way? One theory might be that, given their large endowments, which run into the billions of dollars, they acted voluntarily to appease their critics before they were taxed by the government (Segarra 2007). This element of actual or threatened government coercion, we note, is central to the merit good thesis, since the private "laws" of supply and demand will fail to satisfy society's demand for goods like health care and education. As we will discuss in more detail below, activists may supplant the coercive role of governments by, for example, "threatening" private firms (say pharmaceutical manufacturers) with boycotts or with bad publicity if they do not promote greater access of goods that they believe should be allocated on the basis of merit.

Why doesn't society simply transfer income to the poor so that they can buy a Harvard education if they so desire? As James Tobin pointed out many years ago, the merit good argument provides an example of what he calls "specific egalitarianism," 
meaning that society is often willing to provide specific interventions (e.g. vouchers and food stamps) rather than general income support ${ }^{4}$, since the recipients of the merit good might not choose to buy the desired amount on their own (Tobin 1970). Another way to phrase the merit good argument is in terms of "paternalism," meaning that some members of society (say public officials) know better than other individuals what people really need in order to live a better life. The founder of merit good theory, Richard Musgrave (1959), put it thus: "While consumer sovereignty is the general rule, situations might arise, within the context of a democratic community, where an informed group is justified in imposing its decisions upon others..." (Musgrave 1959, 14).

We note that, in the global context, paternalism often takes the form of "activists" or "policy entrepreneurs" in wealthy societies deciding what it is that consumers in "poor societies" really need and by providing funding for certain goods and services that effectively shape a given society's consumption in a way that might well be different from the consumption that would be generated by consumers who were instead given additional income directly. While "paternalism" certainly has a negative connotation, we should remember that governments often act paternalistically on behalf of social welfare. Thus, mandatory health insurance (as in England) and universal and mandatory primary education (as in nearly all the advanced industrial states) provide examples of governments violating consumer sovereignty. In short, the production of merit goods generally requires some degree of interference in the marketplace in order to match supply and demand (Musgrave 1959). Below, we will discuss in greater detail the

\footnotetext{
${ }^{4}$ We thank Kim Elliott for emphasizing this point.
} 
specific types of interference in markets that might be required in order to match merit good production and consumption.

Crucial to the merit good framework that we will elaborate is the assumption of a society $\mathrm{H}$ in which some members (call them "activists" although they might also be called "policy entrepreneurs") are altruistic (Rotemberg 2008), meaning that their utility function is given by $U=\left(U^{i}, U^{f}\right)$, where $U^{i}$ refers to the individual's "own" utility and $U^{f}$ refers to the utility of someone else, say "the global poor." More generally, we suppose that society $\mathrm{H}$ gets utility from the consumption of merit goods $(\mathrm{m})$ both at home $(\mathrm{H})$ and abroad $(\mathrm{F})$, such that $\mathrm{H}=\mathrm{U}\left(\mathrm{m}^{\mathrm{H}}, \mathrm{m}^{\mathrm{F}}\right)$. Suppose further that $\mathrm{m}$ is produced by a monopolist (Z) in the home country (say a pharmaceutical company) whose profits are given by marginal revenues $(\mathrm{MR})$ that are greater than marginal costs $(\mathrm{MC})$, so that:

$\mathrm{Z}=\pi=(\mathrm{MR} \geq \mathrm{MC})$. We also assume that the demand for the merit good (such as a drug) is price inelastic, so that $\eta<1$, allowing $Z$ to make a significant rent from the sale of $\mathrm{m}$. Indeed, given Z's objective of profit maximization and the prices that it sets for $\mathrm{m}$, there are large numbers of consumers who are unable to purchase the good due to insufficient income.

Now when activists analyze this situation with respect to $\mathrm{m}$, they find that there is "under-consumption" of the good, meaning less consumption than they deem socially desirable. From a merit goods perspective, therefore, the fundamental challenge for our altruists (qua activists or policy entrepreneurs) is to increase consumption of $m$ by the “deserving poor." This, however, requires a series of actions on both the demand and supply sides of the equation. 
On the supply side, it is apparent that several possible solutions present themselves, assuming for the moment that constrained demand or under-consumption is mainly a function of high prices or inadequate incomes; more on this point below. First, society $\mathrm{H}$ can raise taxes $(\mathrm{T})$ in order to transfer income to $\mathrm{F}$ via foreign aid, enabling $\mathrm{F}$ to buy more of the merit good at the home price. The political challenge here is that the "least advantaged" and non-altruistic members of $\mathrm{H}$, qua voters, must agree that transfers to $\mathrm{F}$ work to their benefit.

Second, society $\mathrm{H}$ can induce donations from wealthy individuals (e.g. via tax breaks) to pay for the merit goods which are then transferred overseas to F; here, an organization like the Gates Foundation comes to mind, which uses funds donated by Bill Gates and Warren Buffett to fund all sorts of developing world needs in such areas as health care and education (see www.gatesfoundation.org). However, the funding from such organizations is likely to be small compared to level of global needs that exist.

Third, society $\mathrm{H}$ can induce its firms $\mathrm{Z}$ to donate the merit goods to society F; this approach will have similar shortcomings to those noted above with any philanthropy, with the added problem being that corporate donations may ebb and flow depending upon general market conditions.

Fourth, society $\mathrm{H}$ can produce the merit good in question and then donate it overseas, or it can encourage competition from other producers (e.g. generic manufacturers in the case of drugs) so that the monopoly price falls to the level of marginal cost, say by reducing the amount of intellectual property protection that the monopolist can claim on its products. 
Fifth and finally, $\mathrm{H}$ can encourage $\mathrm{Z}$ to engage in "differential pricing" of the merit good such that prices in society F are lower than they are in the home market. As we will see, it is the combination of solutions four and five-generic competition and differential pricing - that became the economic basis for ARV delivery in the developing world.

Why is that the case? The argument made by ARV activists at the turn of the millennium was that drug donation and charitable giving programs were basically "not sustainable" (Consumer Project on Technology (CPT) et al. 2001). Sustainability, the activists claimed, required a pricing scheme that reconciled the needs of the poor for cheap drugs with incentives to induce the pharmaceutical companies to continue their investments in research and development (R\&D). Differential pricing, with the price in developing countries equal to something like marginal cost, was touted as reconciling profits with the provision of merit goods (Kremer 2002).

In making the case for differential pricing, the activists rightly claimed that drug companies had long practiced price discrimination across the world's various markets for their pharmaceutical products. In many European countries, for example, the government bargained with the companies over drug prices as they made purchasers on behalf of national health systems. In the United States, in contrast, drug purchases remained fragmented, and in essence American consumers provided international drug markets with something like "hegemonic stability," effectively subsidizing pharmaceutical R\&D for the entire world with the high prices they paid at the pharmacy.

Supporting the activists in this line of reasoning was an ongoing research program by economists concerned with health access issues. Pioneering papers by Danzon and 
Towse and Lanjouw and Jack made the analytical case that differential or Ramsey pricing reconciled the needs of profit-seeking firms with the demands of the poor for low-cost drugs (Danzon and Towse 2003; Jack and Lanjouw 2005). These scholars pointed out that many regulated industries adopted "Ramsey pricing," in which different prices were set for different classes of consumers. On both ethical and economic grounds, therefore, Ramsey pricing seemed to provide the most promising framework for achieving universal access to ARVs.

Ramsey pricing works as follows. Suppose the firm's objective function is to maximize profits such that $\mathrm{R}=(\Sigma \mathrm{p}-\mathrm{c})$ : where $\mathrm{R}$ (revenue) $=$ the sum of $\mathrm{p}$ (prices) $-\mathrm{c}$ (costs). We assume that the company produces everywhere at the same marginal cost and, as previously noted, the firm exercises monopoly power, say through a patent. If it exercises monopoly power it can therefore price differently in each market so long as it can effectively segment these markets ${ }^{5}$, setting high prices where the price elasticity is low and lower prices as the price elasticity rises. Many utilities, for example, price water and electricity in this way; industrial consumers that require these utilities in order to produce goods and services often pay higher prices than households.

The question then arises: if a monopolist will "naturally" engage in Ramsey pricing, why didn't the pharmaceutical industry follow suit by offering low prices for ARVs to the developing world at the outset of the AIDS crisis? There are several reasons as to why the drug companies did not act in this way. To begin with, the multinational pharmaceutical companies doubted whether the developing world even provided a market for these drugs at any price, given the limitations of the existing health infrastructure

\footnotetext{
${ }^{5}$ We thank Kim Elliott for emphasizing this point.
} 
coupled with skepticism about whether patients would follow a strict treatment regimen. They also doubted whether they could enforce market segmentation and prevent the reexportation of low-cost drugs back to the industrial world. There were thus supply side constraints that prevented firms from promoting the globalization of ARV treatment.

On the demand side, poor countries had no interest in importing high-cost ARVs because the price was much more than they could afford. Further, the absence or deficiencies in health infrastructure meant that extending access entailed substantial costs beyond the purchase of drugs, placing a strain on stretched health budgets; and in any event, it was unclear whether ARV purchases would be or even should be the first priority of developing world health ministries. Even if they were, procurement and delivery mechanisms would have to, in many cases, be created from scratch, delivering drugs to rural areas over poor roads, with irregular electricity to areas that needed clinics and storehouses and procedures to manage all of that activity (Kremer 2002, summarizes market failures for pharmaceuticals in the developing world).

Alongside these considerations, there was also a widespread perception—often articulated even by those in positions of authority - that the victims of AIDS in the developing world, notably in Africa, lacked the behavioral attributes necessary to make ARV treatment effective. USAID Administrator Andrew Natsios famously argued in 2001 against treatment on the grounds that in Africa, "People do not know what watches and clocks are. They do not use Western means for telling time. They use the sun" (House International Relations Committee 2001). A vicious circle was thus created which prevented the market from being established. 
Essentially, policy entrepreneurs like Peter Piot of UNAIDS—along with activists based within such organizations as Doctors without Borders, Partners in Health, Oxfam and later the Clinton Foundation—-brought together the pharmaceutical manufacturers with developing world governments by negotiating the lower prices at which demand would kick in and by showing through "proof of concept" demonstration efforts that ARV uptake was medically feasible in poor country settings. In 1997, Brazil began to provide ARV therapy to people with HIV, including locally manufactured generic drugs, while in Haiti, Partners in Health led by Dr. Paul Farmer extended treatment to another resource poor setting. Among the other significant programs in this respect was the UN's Drug Access Initiative of 1997-1998 which used Cote D'Ivoire, Vietnam, Thailand, and Chile as pilot countries for exploring the feasibility of universal access to treatment (UNAIDS 1998). So long as the prices paid by governments or philanthropies covered production costs, at least some firms would be prepared to increase output; and so long as prices were low enough the countries (perhaps using foreign aid funds) would be able to buy the drugs. Again, the role of the activists was to construct the market for merit goods by matching demand and supply. On the supply side, drug companies were encouraged to lower the prices on their patented ARVs while generic drug suppliers were encouraged to enter developing world markets. On the demand side, activists won substantially higher amounts of foreign aid funding from the United States and other industrial world governments, specifically targeted at ARV purchases.

Indeed, the activists' cause of advancing universal access was, paradoxically, assisted by ongoing developments regarding the Trade in Intellectual Property Rights (TRIPS) provisions of the Uruguay Round trade agreement of 1993 and its specific 
application to public health. These provisions required all members of the World Trade Organization (WTO), including developing countries, to put into place effective protections on intellectual property (IP), including patents on pharmaceutical products. The least developed countries, however, were given until 2006 (later extended to 2016) to create enforceable TRIPS mechanisms. The TRIPS agreement allowed countries in principle to retain the possibility of issuing compulsory licenses for drugs to generic manufacturers, requiring them only to do so (1) with specific review and authorization, (2) that rights holders be compensated and (3) that a reasonable attempt to obtain a voluntary license had to be made. In instances of national emergencies, countries did not even have to seek a voluntary license from manufacturers (Fink 2008). However, pressure from the United States and other advanced countries to protect IP and limit the use of compulsory licensing made developing countries less secure about what rights they effectively possessed under TRIPS. This lack of clarity would give rise to the 2001 Doha health exception, which specified what rights developing countries had with respect to pharmaceuticals drugs and health emergencies. The 2001 exception only specified the rights of producing countries to grant compulsory licenses, and a TRIPS waiver for poor countries that lacked manufacturing capacity to import generics drugs from abroad was negotiated in August 2003 (Fink 2005; Fink and Elliott 2008; Elliott and Fink 2008).

South Africa's experience in the late 1990s with aggressive IP protection by pharmaceuticals companies and rich country governments set the stage for the important developments in 2001 and 2003 that would enshrine more explicit protection of developing country rights with respect to health and pharmaceuticals. In 1997, South Africa passed a "Medicines Act" which legalized measures to reduce the price of 
patented drugs through parallel importation and compulsory licensing, which would potentially have enabled the South African government to import low-cost generic versions of ARVs from abroad. The Pharmaceutical Manufacturers Association of South Africa (made up of the multinational drug companies) sued the Government over the Medicines Act, with the support of the United States and European Union, both of which tried to pressure the government to rescind the Act. The suit and these pressures were hugely counter-productive, in that they unleashed a massive activist campaign against the pharmaceutical industry, which won sympathy even from the likes of The Wall Street Journal (Cooper, Zimmerman, and McGinley 2001). By 2001, in the face of continuing opposition, the industry dropped this suit.

In the meantime, as a Federal Reserve Bank of New York economist reported, “Indian and Brazilian generics companies' low prices began to put pressure on originator companies to reduce their prices in low- and medium-income countries. For example, competition from generics producers...forced the average branded price of an AIDS triple-combination therapy from $\$ 10,439$ per year to less than $\$ 1,000$ per year in 2000 " (Hellerstein 2004). As Table 1 suggests, the price of three out of four "first-line" cocktails has fallen substantially since 2004 (and indeed since 2001) thanks to pressure from generic competition, coupled with bulk purchases made possible by such organizations as the Clinton Foundation.

As prices fell, activists moved to increase public (and charitable) spending to buy antiretrovirals for those with AIDS in the developing world. Two major programs would be launched with this objective in mind: first, the Global Fund to Fight AIDS, Tuberculosis and Malaria in 2002, and then in 2003, in the United States, the President's 
Emergency Plan for AIDS Relief (PEPFAR). These vehicles have since become by far the world's largest sources of funding for AIDS treatment and prevention programs. The Global Fund was created as a separate institution outside UNAIDS largely because the United States did not trust the United Nations to run a major, heavily funded new program (Kazatchkine 2009). For its part, PEPFAR represented a coalition of political interests that bridged AIDS activists and development campaigners on the left with the evangelical community on the right that had found religious motivation in helping those with HIV. A notable example is provided by Franklin Graham, son of Billy Graham and head of Samaritans' Purse, a Christian relief charity, who brought long-time critics of foreign aid like Senator Jesse Helms to believe that addressing AIDS was a moral calling for all evangelists. Another key figure who helped build this bridge was none other than Bono, who, as already noted could talk "Christian to Christian" with political leaders like President Bush and Senator Helms, while holding his own with those focused more on the disease and, in particular, on its ravaging effects in Africa (Busby 2007; Gerson 2007; Burkhalter 2004; Lefkowitz 2009; Behrman 2004; Dietrich 2005).

In short, the goal of creating a universal access regime required that both the material and the ideational pieces of this political campaign fall into place. On the material side, advocates needed to overcome the market failures that discouraged producers from supplying drugs to the developing world and that prevented poor consumers from obtaining access. Prices were a significant barrier, but concerns about efficacy and infrastructure presented additional impediments to extending access to treatment. But changing the material context also required an ideological commitment to the objective of universal access. Without the cosmopolitan ethical motivation that all 
people had a right to ARV treatment — that ARVs were indeed merit goods - the global fight against AIDS may well have languished. As we will see in the following section, that ethical motivation translated into political opportunities for leaders to support the cause of universal access, particularly in the United States.

\section{Why the AIDS Treatment Campaign Succeeded}

The success of the AIDS advocacy movement in generating a massive scale-up of ARV treatment naturally leads to the question, why was this particular campaign successful while many others both within and outside global health policy (e.g. the elimination of small arms, the reduction of carbon emissions; the Save Darfur Coalition) have failed or enjoyed much less success? Put a little differently, if the AIDS campaign was ultimately about the idea of universal treatment being accepted and championed by the international community, why did this policy gain support when many other worthy causes have languished in relative obscurity?

This question is among the most important questions facing scholars of social movements and non-state actors (Price 2003). It also is of intense interest for other campaigns for global public health and international development that all are seeking to emulate the success of the AIDS campaign. We provide a provisional answer to this question in this final section.

As we have already argued, activists have to bring together the material and the moral/ideational pieces of a campaign in order to build coalitions that influence public policy. They not only have to convince policymakers that what the advocacy campaign recommends can be done, they must also must convince them that it should be done. We now look at how these pieces came together to create widespread political support in the 
AIDS case, starting with the material conditions that supported the building of a universal access to treatment regime.

\section{$\underline{\text { Permissive Material Conditions }}$}

While moral and ideational motivations may sometimes convince policymakers to embrace costly commitments (Busby 2007), campaigners must also often make utilitarian or cost-benefit arguments that they are not throwing taxpayer funds down the proverbial rat-hole. To that end, even if HIV/AIDS did not exhibit the characteristics necessary for successful disease eradication, like smallpox or polio, the proof of concept demonstrations in Brazil, Haiti, and other countries succeeded in showing treatment could be effective in the developing world. These early programs were especially important in overturning the presumption that poor people would not adhere to the drug regimen as faithfully as those in the advanced welfare states. The dramatic decline in drug prices brought about by competition from generic ARV suppliers also persuaded policymakers that treatment was now within the realm of affordability. Further, unlike prevention programs, the number of ARV treatments being provided to patients could readily be counted; politicians could thus set numerical targets whose progress could easily be followed.

Furthermore, the ARV campaign was critically helped by the growth of the global economy during the early 2000 s. The counterfactual we have to ask ourselves is this: if the movement for access to treatment was mobilizing for the first time in 2009 , in the midst of the worst global economic downturn in decades, would donor countries be as enthusiastic and as generous? As global campaigns for clean water and universal 
education now seek to replicate the success of AIDS campaigners, it will be interesting to see if the structural conditions in the global economy put those goals out of reach. ${ }^{6}$

Still, despite the favorable circumstances fostered by the combination of successful demonstration projects, declining drug prices, and a healthy global economy, a permissive material context was not enough to build a broad political coalition in support of the campaigners' aims. Why did decision-makers decide to promote and fund AIDS programs and not something else? It is this question to which we now turn.

\section{The Politics of AIDS Treatment}

Potentially, there are a number of different answers to explain why AIDS treatment campaigners were able to convert permissive material conditions into widespread political support. In this section, we examine several possibilities that have been offered in the literature: the degree of policy consensus; the attributes and expertise of AIDS activists; and, related, the messages and frames provided by the treatment campaign. We suggest that none of these on their own is sufficient to explain the emergence of the access to treatment regime; instead, AIDS activists relied on each factor as they worked to forge a broad political coalition.

\section{Degree of Policy Consensus.}

Shiffman and Smith have examined in detail the tragic failure of campaigners to win enhanced international support to protect maternal mortality (Shiffman and Smith 2007;

\footnotetext{
${ }^{6}$ Donor countries might still find the resources to support foreign aid even in tough times. In the 2009 G-8 meeting in Italy, the world's advanced industrialized countries committed to $\$ 20$ billion for an expanded food security program. That said, this could be like the pledge from 2005 Gleneagles G8 meeting of $\$ 50$ billion in additional aid for developing countries, which subsequently did not fully materialize.
} 
Youde 2008, discusses the failure of the universal primary health care norm). Their ultimate conclusion was that campaigners lacked consensus on a policy prescription. When too many ideas are at play, policy change is less likely. Thus, if this hypothesis is correct, the AIDS treatment campaign was ultimately successful because the movement coalesced towards a single consensus view of what was needed—greater access to ARVs - while other health concerns and other campaigns for maternal mortality or population control have lacked a single defining prescription.

To that end, the success of treatment could be contrasted with the AIDS prevention agenda, which has been much more politicized and divided between conservative voices that support abstinence and liberals that support condom use. Inspired by Uganda's success, campaigners sought an overarching approach to prevention that tied these concerns together (the $\mathrm{ABC}$ campaign of Abstinence, $\mathrm{Be}$ faithful, and Condoms). However, this agenda has failed to capture unanimity of purpose among campaigners and arguably the prevention agenda has faltered in the field.

While an argument focusing on the degree of policy cohesion is attractive in its simplicity, it cannot alone explain why decision-makers would be persuaded to support movement aims. After all, as Pranab Bardhan points out, there is a fair degree of cohesion around the correct treatment for children dying from diarrhea—oral rehydration therapy — and yet here is another case where the campaign for greater access to treatment has failed to capture the attention of senior policy leaders. ${ }^{7}$ Cohesion may be a necessary condition for movement success, but it is probably insufficient.

\footnotetext{
${ }^{7}$ We thank Bardhan for making this point in a personal communication.
} 


\section{Activist Attributes and Expertise.}

While generally frowned upon as an explanation in the political science literature, it is difficult to deny that much of the ARV treatment regime's relative success ultimately has to do with the quality of the individuals involved in this campaign, just as it would be hard to imagine modern Singapore without Lee Kuan Yew or South Africa without Nelson Mandela. One could argue that the characters involved in this story, such as Peter Piot, Bono, Franklin Graham, Paul Farmer, Jonathan Mann, and many others, had unusually strong persuasive skills. They combined substantive expertise with evangelical fervor, and they also exploited diffuse social networks that extended throughout the political and economic realms.

However, that observation begs the question about what attributes of their personality or expertise gave them such influence. Busby provides a partial explanation based on the individual attributes of these campaigners, drawing on findings from political psychology. He suggests that advocates like the evangelist Franklin Graham were persuasive because they shared a number of attributes (religion, ideology, gender, age) in common with key decision-makers like George W. Bush. And for his part, Bono was able to exploit his shared religious beliefs with Bush and many leaders of Congress (Busby Unpublished manuscript).

A different argument about advocate characteristics would focus on the shared scientific expertise of medical professionals (Haas 1992). As already noted, AIDS experts like Peter Piot and Paul Farmer were converted early to the belief that ARV treatment should be extended globally, and they helped create an "epistemic community" of likeminded advocates. But there are a number of other health conditions in the developing 
world that are responsible for as many, if not more premature deaths than AIDS, and whose solutions are relatively straightforward. As previously noted, diarrheal diseasewhich can readily be reduced by access to clean water and better sanitation and for which effective treatments already exist—killed 1.81 million people in 2004 compared to 1.51 million who died from AIDS (WHO 2008a).

Where is the campaign to end infant deaths from diarrhea? Why were decisionmakers compelled to act on AIDS and not these other causes? As climate scientists have discovered, scientific expertise, on its own, is often not enough to convince decisionmakers to act. Other arguments other than the basic facts of the situation are often needed to persuade decision-makers that action is necessary.

\section{Messages/Frames.}

Another way, therefore, to explain the AIDS campaign's success is to look at advocates' messages and how they framed the problem. Only a handful of issues rise to the attention of busy policymakers. Whether an issue gets their attention is sensitive to the episodic flow of events and crises. Even when annual gatherings like the Group of Eight (G-8) summit focuses decision-makers' attention on causes to promote, these causes do not arise spontaneously. Activists are required to champion a problem, frame how it is interpreted, and suggest possible remedies. ${ }^{8}$

Frames can tap into different logics. A frame that suggests "AIDS is a national security threat" seeks to legitimate a certain causal belief about the disease's consequences and its implications for the target's interests. By contrast, a frame that

\footnotetext{
${ }^{8}$ Framing is imported from the social movement literature in sociology pioneered by Zald, Snow, Tarrow and others. Frames serve as mental short-cuts by which policymakers can sort information and understand a problem's causes, its consequences, and what solutions exist (Zald 1996, 262).
} 
suggests "AIDS demands compassion for the sufferers" is governed more by a logic of appropriateness. ${ }^{9}$

While advocacy groups often adopt a dominant frame, they may also employ multiple messages to appeal to different groups, building political coalitions in the process. For example, HIV/AIDS has been framed as a public health issue, a human rights issue, a justice issue, a moral problem, an issue of intellectual property rights, and a security problem. The ethical/human rights-based argument was perhaps the most central frame that animated advocates' demands internationally (though security arguments were far from trivial at the United Nations - see Behrman 2004), but there has been some local variation, with the moral frame having a decidedly more Christian religious flavor in the United States. Framing can determine whether political coalitions will be built, whether the issue in question then gets on the agenda, and what policy instruments and resources are mustered to address the problem.

However, as critics of framing arguments have pointed out, what determines why one particular frame wins, particularly when frames are competing against each other (Payne 2001)? Thus far, scholars of framing have yet to offer an adequate answer to this question.

\section{Building Coalitions and Overcoming Opposition.}

We try to pull these disparate ideas together by focusing on the role of political coalitions and on the strength of the opposition. In order to succeed politically, campaigns have to have broad support while overcoming the major sources of potential

\footnotetext{
${ }^{9}$ For this distinction, see (March and Olsen 1998) As Sell and Prakash argue, actors that promote logics of appropriateness often have intermingled concerns about consequences, whether it be organizational survival or funding. Likewise, businesses that seemingly care only about consequences also believe their actions are right (Sell and Prakash 2004).
} 
political opposition. From this perspective, the nature of the issue area can have a big effect on the relative success of different campaigns by changing the balance between coalitions and opponents. For example, advocates of climate change policy have sought to build a broad coalition drawn from both environmental and industrial groups - and increasingly from evangelical organizations as well—but they have confronted influential interest groups in the power generation sector. Much of the active opposition to AIDS treatment, however, had been largely nullified by the turn of the millennium, at least in the industrial world (ironically, this was not the case in countries like South Africa, where public officials continued to dispute the efficacy of the ARV regimen).

Who were the potential opponents of extending AIDS treatment programs? These included pharmaceuticals companies that were worried about profits, social conservatives who identified AIDS with a sinners' disease, and fiscal conservatives opposed to foreign aid spending. While an exhaustive analysis of the way AIDS campaigners muted or transformed the opposition is beyond the scope of this paper, the important point to takeaway is that AIDS activists succeeded by reducing the political costs of supporting AIDS treatment. By creating a campaign with some cachet on both left and right, AIDS activists made their cause broadly attractive. Given that the potential opposition in the United States was concentrated on the political right, it was especially important to make in-roads among evangelicals and social and fiscal conservatives who could vouch for the policy. A synthetic account of how activists succeeded would focus on key countries like the United States and marry the discussion of activists with messages and focus on the role of advocates like Franklin Graham who made religious appeals to policy 
"gatekeepers" like the conservative Senator Jesse Helms of the Foreign Relations Committee (Busby Unpublished manuscript).

In sum, we would expect campaigns to be more successful when they (1) enjoy permissive materials conditions; (2) provide a coherent policy prescription; and (3) build a broad political coalition on the one hand while facing few influential political opponents on the other. With the AIDS case, activists were favored along each of these three dimensions. However, given the rising financial costs of cutting-edge "second line therapy," continuing disappointment with the prevention agenda, the soaring numbers of people needing treatment, and the deterioration in the global economy, we share Mead Over's concerns about whether the AIDS treatment regime is sustainable over the longrun (Over 2008).

\section{Conclusions}

In this paper, we have demonstrated the role of activists and policy entrepreneurs in building a market for ARVs in the developing world. By naming and shaming pharmaceutical companies and by promoting generics, the price of this treatment was greatly reduced, making the goal of universal access seemingly feasible rather than "pie in the sky." With lower prices, the activists pressured governments to provide more foreign assistance for the purchase of ARVs, bringing the supply and demand sides of the equation together. Activists thus succeeded in transforming ARVs from private goods into merit goods that everyone had the right to consume.

In thinking about the future, the AIDS treatment campaign raises several important questions for policymakers. First, can ARV treatment access continue to be extended? Second, should the merit goods model be extended to other domains where 
access is currently limited and highly unequally distributed internationally? And third, can other campaigns (e.g. for universal access to education and clean water) replicate the success of the AIDS treatment campaign politically?

With respect to maintaining and extending ARV access, the answer is not a simple one. To the extent that the virus that causes AIDS will continue to mutate and generate drug resistance, branded pharmaceuticals companies are needed to develop new drug therapies for AIDS. These companies continue to press for maximal protection of intellectual property rights, and as drug resistance among first-line ARV drugs becomes more prevalent, it will become increasingly expensive to provide second line drugs, since these are facing less competition from generic producers.

At the same time, the failure of AIDS prevention strategies is straining budgets at a time when governments are under unprecedented pressure to cut costs. For these reasons, a growing number of observers are expressing concern about the future sustainability of the global AIDS regime (Over 2008). Reneging on the commitments made to the more than three million people on ARV therapy would be morally indefensible. But advocates for AIDS broadly need to spur a renewed focus on prevention since the funds available for treatment will never be large enough to cover those in need, so long as the HIV positive community continues to swell.

This raises the question of whether the case of ARVs could or should be extended to other domains, in health or potentially other issue-areas. Drug companies have no incentive to invest in cures or treatment therapy for so-called orphan diseases like malaria, Chagas disease, and filariasis, primarily because advanced industrialized countries are not (or no longer) affected by them. Private donors like the Gates 
Foundation as well as official donor money will be required to incentivize the production of drugs for those diseases. For differential pricing of medicines to work, there needs to be a reservoir of rich country consumers who are willing to pay monopoly prices while subsidizing the rest of the world's consumption. Interestingly, activists like those from the Lance Armstrong Foundation are beginning to globalize their struggle for cancer treatment along these lines (Lance Armstrong Foundation Undated). But as we have shown, differential pricing can only work in this and other arenas (such as seeds, books, and software) if activists are successful in making a case for this scheme with a broad coalition of interests. Inevitably, this will require some efforts to bring in the private sector generators (and copiers) of this intellectual property, and in many cases, this will require overcoming market failures on both the demand and supply side.

Economists typically see the emergence of differential pricing as a "natural" market response to monopolistic production, citing the pricing practices of pharmaceutical companies as a paradigmatic case. But there is a world of difference between selling drugs at somewhat lower prices in Canada than in the United States (because of the differing role played by government in these countries in negotiating with the manufacturers) and in selling them at close to or at marginal cost. When asked why his company had reduced the prices of ARVs in developing countries, for example, the CEO of Abbott Laboratories said: “Frankly, because it is required. If I don't provide our products in Africa, governments will license our intellectual property to others who can. Governments will intervene. Make no mistake, they will do that" (Quoted in Shadlen 2007, 576). As these comments suggest, the market for ARVs was a political no less than an economic construction. If the merit goods model (and the role of differential pricing 
within it) are to play a more expanded role in other areas, then policymakers may need to build institutions that enable the private sector to embrace this scheme (for example by ensuring effective market segmentation and protecting property rights) in order to avoid some of the more bruising confrontations between advocates and the business community.

The metaphor of extended access is itself being extended to new domains, like education and water where activists have seized upon the AIDS treatment campaign's success for inspiration. Unlike medicines (and software and seeds), education and water are largely location-specific: they are not transferable from advanced world markets even if there are positive externalities associated with investing in these sectors. In these cases, however, differential pricing is unavailable as a model. Thus, the solution set for both problems is even more dependent upon donor financing and idiosyncratic local implementation than the AIDS treatment regime. That may not prevent either cause from mustering political support, but it is interesting to note that very specific development programs (like PEPFAR) are much more politically popular than broad-based financial assistance to well-run governments to spend as they see fit (i.e. the Millennium Challenge Corporation). That said, at a time when donor governments' foreign assistance budgets are already strained, campaigns for extended access will have to compete with a profusion of other issues for attention.

In conclusion, if activists are to succeed, they must bring together a broad coalition of interests as they transform private goods into merit goods that are available to all. This coalition, in turn, must be joined by a convergent idea of what can and should be done. It is only through the fusion of a compelling set of ideas about how the world 
should work with favorable material conditions that activists will bring change to the global economy. 
Table 1: Median price (United States dollars) of first-line antiretroviral drug regimens in low-income countries, 2004-2007

(Source: World Health Organization, 2008).

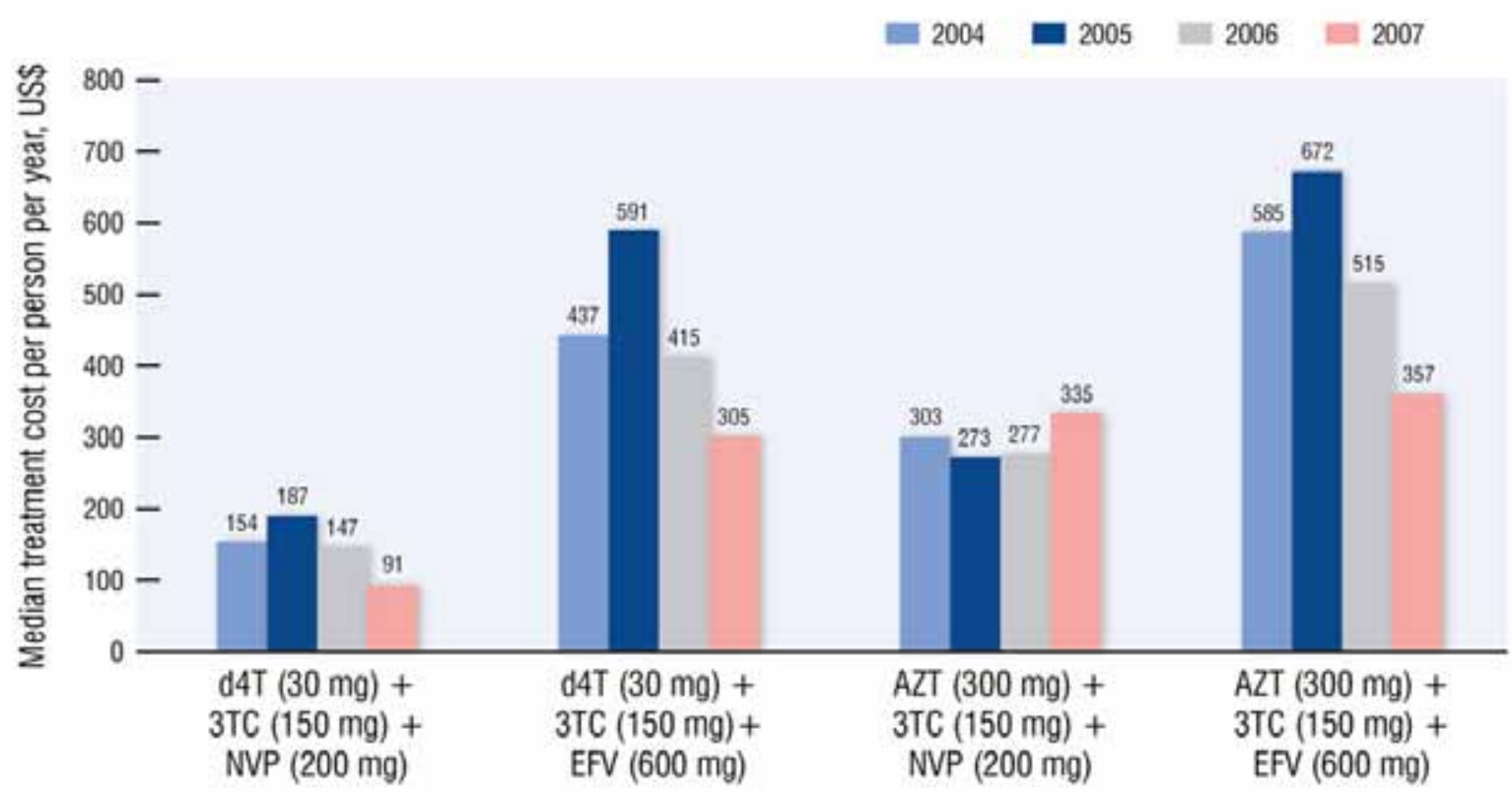

d4T: stavudine; 3TC: lamivudine: NVP: nevirapine; EFV: efavirenz; AZT: zidovudine. 


\section{Bibliography}

Attaran, Amir, and Jeffrey Sachs. 2001. Defining and refining international donor support for combating the AIDS pandemic. The Lancet 357 (9249):57-61.

Barnett, Tony, and Alan Whiteside. 2002. AIDS in the twenty-first century : disease and globalization. Houndmills, Basingstoke, Hampshire ; New York: Palgrave Macmillian.

Barrett, Scott. 2006. The smallpox eradication game Public Choice 130:179-207.

Bartley, Tim. 2007. Institutional Emergence in an Era of Globalization: The Rise of Transnational Private Regulation of Labor and Environmental Conditions. American Journal of Sociology 113 (2):297-351.

Behrman, Greg. 2004. The invisible people : how the U.S. has slept through the global AIDS pandemic, the greatest humanitarian catastrophe of our time. New York: Free Press.

Brown, David. Vaccine Failure Is Setback in AIDS Fight. Washington Post, March 21 2008. Available from http://www.washingtonpost.com/wpdyn/content/article/2008/03/20/AR2008032003398.html?hpid\%3Dtopnews\&sub= AR.

Burkhalter, Holly. 2004. The Politics of AIDS: Engaging Conservative Activists. Foreign Affairs, 8-14.

Busby, Josh. 2007. 'Bono Made Jesse Helms Cry': Debt Relief, Jubilee 2000, and Moral Action in International Politics. International Studies Quarterly 51 (2):247-275.

Busby, Joshua. From God's Mouth - Messenger Effects and the Politics of the Global AIDS Response in the United States. University of Texas Unpublished manuscript.

Consumer Project on Technology (CPT), Health Action International (HAI), Médecins sans Frontières (MSF), and Oxfam and Treatment Action Group (TAG). Joint Statement on Differential Pricing \& Financing of Essential Drugs. April 112001. Available from http://www.cptech.org/ip/wto/norwaystatement.html.

Cooper, Helene, Rachel Zimmerman, and Laurie McGinley. 2001. AIDS Epidemic Puts Drug Firms In a Vise: Treatment vs. Profits. Wall Street Journal, March 2.

d'Adesky, Anne-christine. 2004. Moving Mountains: The Race to Treat Global AIDS. New York: Verso.

. Pills Profits Protest - Voices of Global AIDS Activists. Outcast Films 2005.

Danzon, Patricia M., and Adrian Towse. 2003. Differential Pricing for Pharmaceuticals: Reconciling Access, R\&D and Patents. International Journal of Health Care Finance and Economics, 3:183-205

de Waal, Alex. 2006. AIDS and Power: Why there is no Political Crisis - Yet. London: Zed Books.

Dietrich, John W., ed. 2005. The George W. Bush foreign policy reader. Armonk, NY: M.E. Sharpe.

Elliott, Kimberly, and Carsten Fink. Tripping Over Health: U.S. Policy on Patents and Drug Access in Developing Countries (White House and the World Policy Brief). Center for Global Development, November 4 2008. Available from http://www.cgdev.org/content/publications/detail/967265.

Elster, Jon. 1993. Local Justice: How Institutions Allocate Scarce Goods and Necessary Burdens. New York: Russell Sage. 
Fink, Carsten. Intellectual Property and Public Health: The WTO’s August 2003 Decision in Perspective. World Bank 2005. Available from http://siteresources.worldbank.org/INTRANETTRADE/Resources/InternalTraining/6 Carsten Health15 Pubhealth.pdf. . Intellectual Property and Public Health: An Overview of the Debate with a Focus on US Policy, Working Paper Number 146. Center for Global Development, June 2008. Available from http://www.cgdev.org/content/publications/detail/16228/.

Fink, Carsten, and Kimberly Elliott. 2008. Tripping over Health: U.S. Policy on Patents and Drug Access in Developing Countries. In The White House and the World, edited by N. Birdsall. Washington, DC: Center for Global Development.

Fleet, Julian, and Bechir N'Daw. 2008. Trade, intellectual property and access to affordable HIV medicines. In The HIV Pandemic: Local and Global Implications, edited by E. J. Beck, N. Mays, A. W. Whiteside and J. M. Zuniga. Oxford: Oxford University Press.

GAO. Global Fund to Fight AIDS, TB and Malaria Has Improved Its Documentation of Funding Decisions but Needs Standardized Oversight Expectations and Assessments. United States Government Accounting Office, May 2007. Available from http://www.gao.gov/new.items/d07627.pdf.

Garrett, Laurie. 1994. The Coming Plague. New York: Penguin Books.

Gellman, Barton. 2000. DEATH WATCH: The Global Response to AIDS in Africa; World Shunned Signs of the Coming Plague. Washington Post, July 5.

Gerson, Michael. 2007. Heroic Conservatism. New York: HarperOne.

Global Fund. Expenditure Target. Undated. Available from http://www.theglobalfund.org/en/distributionfunding/\#expenditure target.

Gonsalves, Gregg. Scaling Up Antiretroviral Therapy and the Struggle for Health for All. AIDS and Rights Alliance for Southern Africa (ARASA), International Treatment Preparedness Coalition (ITPC), August 7 2008. Available from http://www.tac.org.za/community/node/2397.

Haas, Peter M. 1992. Introduction: Epistemic Communities and International Policy Coordination. International Organization 46 (1):1-35.

Hellerstein, Rebecca. Do Pharmaceutical Firms Price Discriminate Across Rich and Poor Countries? Evidence from Antiretroviral Drug Prices. August 2004.

Available from http:/www.ny.frb.org/research/economists/hellerstein/JDE2.pdf.

House International Relations Committee. Transcript of the Hearing on the U.S. Agency for International Development's (USAID) Fight Against Aids June 72001. Available from http://www.kaisernetwork.org/health cast/uploaded files/hin060701.pdf.

Jack, William, and Jean O. Lanjouw. 2005. Financing Pharmaceutical Innovation: How Much Should Poor Countries Contribute? The World Bank Economic Review 19 (1):45-67.

Johnson, Diane, and John F. Murray. 1988. AIDS Without End. New York Review of Books 35 (13):2-4.

Kaiser Family Foundation. 2006. The Global HIV/AIDS Epidemic, November 2005 [cited April 26 2006]. Available from http://www.kff.org/hivaids/upload/3030-06.pdf. 
—. President Bush Signs PEPFAR Reauthorization Bill. July 31 2008. Available from http://www.kaisernetwork.org/daily reports/rep index.cfm?DR ID=53609.

Kates, Jennifer, Eric Lief, and Carlos Avila. Financing the response to AIDS in low-and middle-income countries: International assistance from the G8, European Commission and other donor Governments in 2008 July 2009. Available from http://www.kff.org/hivaids/7347.cfm.

Kazatchkine, Michel. 2009. Interview with Michel Kazatchkine of the Global Fund, January 30.

Kramer, Larry. ACTUP Oral History Project. A Program of Mix - The New York Lesbian \& Gay Experimental Film Festival, November 15 2003. Available from http://www.actuporalhistory.org/interviews/images/kramer.pdf.

Kremer, Michael. 2002. Pharmaceuticals and the Developing World. Journal of Economic Perspectives 16 (4):67-90.

Lance Armstrong Foundation. Livestrong Action: A World Without Cancer. Undated. Available from http://www.livestrongaction.org/.

Lefkowitz, Jay. AIDS and the President--An Inside Account. Commentary, January 2009. Available from http://www.commentarymagazine.com/viewarticle.cfm/aids-andthe-president--an-inside-account-14057.

Lieberman, Evan. 2009. Boundaries of Contagion: How Ethnic Politics Have Shaped Government Responses to AIDS. Princeton: Princeton University Press.

March, James G. , and Johan P. Olsen. 1998. The Institutional Dynamics of International Political Orders. International Organization 52 (4):943-969.

Musgrave, Richard A. 1959. The Theory of Public Finance. New York: Mcgraw-Hill.

Office of the U.S. Global Aids Coordinator. 2008. PEPFAR: Latest Results. U.S. State Department, September 302007 [cited June 1 2008].

Over, Mead. Prevention Failure: The Ballooning Entitlement Burden of U.S. Global AIDS Treatment Spending and What to Do About It - Working Paper 144. Center for Global Development, May 5 2008. Available from http://www.cgdev.org/content/publications/detail/15973/.

Packard, Randall M. . 1997. Malaria Dreams: Postwar Visions of Health and Development in the Third World. Medical Anthropology 17 (3):279-296.

Payne, Rodger. 2001. Persuasion, Frames and Norm Construction. European Journal of International Relations 7 (1):37-61.

Peterson, Susan, and Stephen Shellman. 2008. AIDS and Violent Conflict: Indirect Effects of Disease on National Security. The College of William and Mary 2006 [cited June 1 2008]. Available from http://www.wm.edu/irtheoryandpractice/security/papers/AIDS.pdf.

Piot, Peter. 2009. Interview with Peter Piot, January 28.

Price, Richard. 2003. Transnational Civil Society and Advocacy in World Politics. World Politics 55:579-606.

Rotary International. International PolioPlus Committee Statements on Current Facts and Figures Relative to Polio Eradication and the Role of Rotary International in the Global Effort July 2007. Available from http://www.rotary.org/RIdocuments/en_pdf/polio_facts.pdf.

Rotemberg, Julio 2008. Minimally Acceptable Altruism and the Ultimatum Game. Journal of Economic Behavior and Organization 66 (3-4):457-474. 
Schwartz, John. 1994. Clinton's AIDS Policy Chief Resigns. Washington Post, July 9.

Segarra, Marielle. Congress Looking At Endowment Spending. CBS News, October 17 2007. Available from http://www.cbsnews.com/stories/2007/10/18/politics/uwire/main3379500.shtml.

Sell, Susan K., and Aseem Prakash. 2004. Using Ideas Strategically: The Contest Between Business and NGO Networks in Intellectual Property Rights. International Studies Quarterly 48 (1):143-175.

Shadlen, Kenneth. 2007. The Political Economy of AIDS Treatment: Intellectual Property and the Transformation of Generic Supply International Studies Quarterly 51 (3):559-581.

Shiffman, Jeremy, and Stephanie Smith. 2007. Generation of political priority for global health initiatives: a framework and case study of maternal mortality. The Lancet 370 (9595):1370-1379.

Smith, Raymond A., and Patricia A. Siplon. 2006. Drugs into Bodies: Global AIDS Treatment Activism. Westport, Conn.: Praeger.

Tobin, James. 1970. On Limiting the Domain of Inequality. Journal of Law and Economics 13 (2):263-277.

UN General Assembly. Resolution adopted by the General Assembly: 60/262. Political Declaration on HIV/AIDS June 15 2006. Available from http://data.unaids.org/pub/Report/2006/20060615_HLM_PoliticalDeclaration_AR ES60262 en.pdf.

UNAIDS. Drug Access Initiative. 1998.

- 2008a. 2008 Report on the global AIDS epidemic. http://www.unaids.org/en/KnowledgeCentre/HIVData/GlobalReport/2008/default asp.

- Global Facts and Figures 2008b. Available from http://data.unaids.org/pub/GlobalReport/2008/20080715 fs global en.pdf.

WHO. Fact Sheet: Top Ten Causes of Death. November 2008a. Available from http://www.who.int/mediacentre/factsheets/fs310_2008.pdf.

- 2008. Towards Universal Access: Scaling up priority HIV/AIDS interventions in the health sector. World Health Organization, June 2 2008b [cited June 2 2008]. Available from http://data.unaids.org/pub/Report/2008/200806_TowardsUniversalAccessReport2 008 en.pdf.

Yekutiel, Perez. 1981. Lessons from the Big Eradication Campaigns. World Health Forum 2 (4):465-490.

Youde, Jeremy. 2008. Is universal access to antiretroviral drugs an emerging international norm. Journal of International Relations and Development 11 (4):415-440.

Zald, Mayer. 1996. Culture, ideology and strategic framing. In Comparative Perspectives on Social Movements, edited by D. McAdam, J. D. McCarthy and M. Zald. Cambridge: Cambridge University Press. 